\title{
APPLICATION OF THE KAIZEN 5S METHOD FOR THE LAYOUT OF THE WAREHOUSE SECTION
}

\author{
M. Nushron Ali Mukhtar', M. Asy'aril Muhajir ${ }^{2}$ \\ Industrial Engineering Study Program, Faculty of Industrial Technology \\ PGRI University Adi Buana Surabaya, Jalan Dukuh in the XII, Surabaya, 60234, Indonesia \\ E-mail: nushronali85@gmail.com
}

\begin{abstract}
Warehouse as a place that is burdened with the task of and items to be used in production, until the goods are requested according to the operating schedule. The purpose of this study is to find out how to place, group, and compile items to be orderly. The average results in preparing the $P O$ after implementation are proven to be faster than before implementation, so $\mathrm{Ho}$ is rejected. Statistical test results with an average ratio that shows the average time before implementation is 16.37 and the results after implementation are 2.04 and it is obviously that after implementation there has been a significant decrease in the service of purchase orders (PO) more fast.
\end{abstract}

Keywords: Warehouse Layout, Kaizen. $5 s$

\section{INTRODUCTION}

Many companies produce Large goods that have problems in the arrangement of finished products in the storage Place . Even with the increasing number of types of products made, often make it difficult for warehouse operators mastermind the search for goods. So to find one item will take a long time. Given the importance of this problem, there needs to be a solution to letak The warehouse layout that can facilitate the Search process.

Some of the problems in the Warehouse such as when taking a finished product that is sent to the customer takes approximately 1 (one) to 2 (hours) because it must moving around other products. Then delivery to costumer time is always late, because it must move the finished product that obstructs the product to be shipped, by Memindah-mindah the other products, then the labor needs will increase so that inefficient as well as the use of storage so that the product is not optimal, the lack of supply shelf. Therefore it is necessary to do the addition of the rack finished products and the layout of the storage of PRof superior design so well and correct. According to (M. Nushron Ali M, 2019) Technical analysis is done precisely and the right time will provide a great value in assisting the decision making process of engineer during design and development. S, according to (Kastoro and Nelfiyanthi, 2007) research on the frequency of moving product goods so out of the warehouse using material handling. The Study Applied The 5s method on the placement of finished goods in the warehouse product AREA at PT. Nobi PUTRA ANGKASAThe technique of Kaizen has been implemented in PT NGK Busi Indonesia Since the beginning of the company's establishment until now. Kaizen technique is assumed to be a practical technique and requires low cost. Implementation of this technique is continuous reduction of waste. It does not depend on investment but relies on the process and the performance of the workers. To support the company's objectives and increase the company's profits, workers apply Kaizen in their respective workplace.(Susilo.R, 2017)

In general, the main problem of Kaizen implementation is the lack of authorization from top management to all employees of the company. The main key of Kaizen technique is the focus on process. To focus on the purpose of each division is the easiest way to apply Kaizen and it will minimize the risk that will arise (Khan, 2011). 5s is one of the concepts of innovation that comes from the Japanese language of Seiri (sort), Seiton (set in order), shine (Shining), Seiketsu (standardization) and (sustained) (Chi, 2011). Most companies generally employ that technique to manage the workplace. The application of the $5 \mathrm{~S}$ technique in Japan started from the manufacturing sector 
which then expanded into industrial sector and service sector (Ohno, 1988).

Based on the explanation above, in this research will be conducted analysis of arrangement of finished goods in the warehouse with the method of Kaizenapproach. It is hoped that this research can help with the problems that occur in the Warehouse division .

\section{RESEARCH METHODOLOGY}

In this research methodology described in the form of a flowchart recognize the steps taken in the study. This methodology is made so that the research carried out according to the discussion.

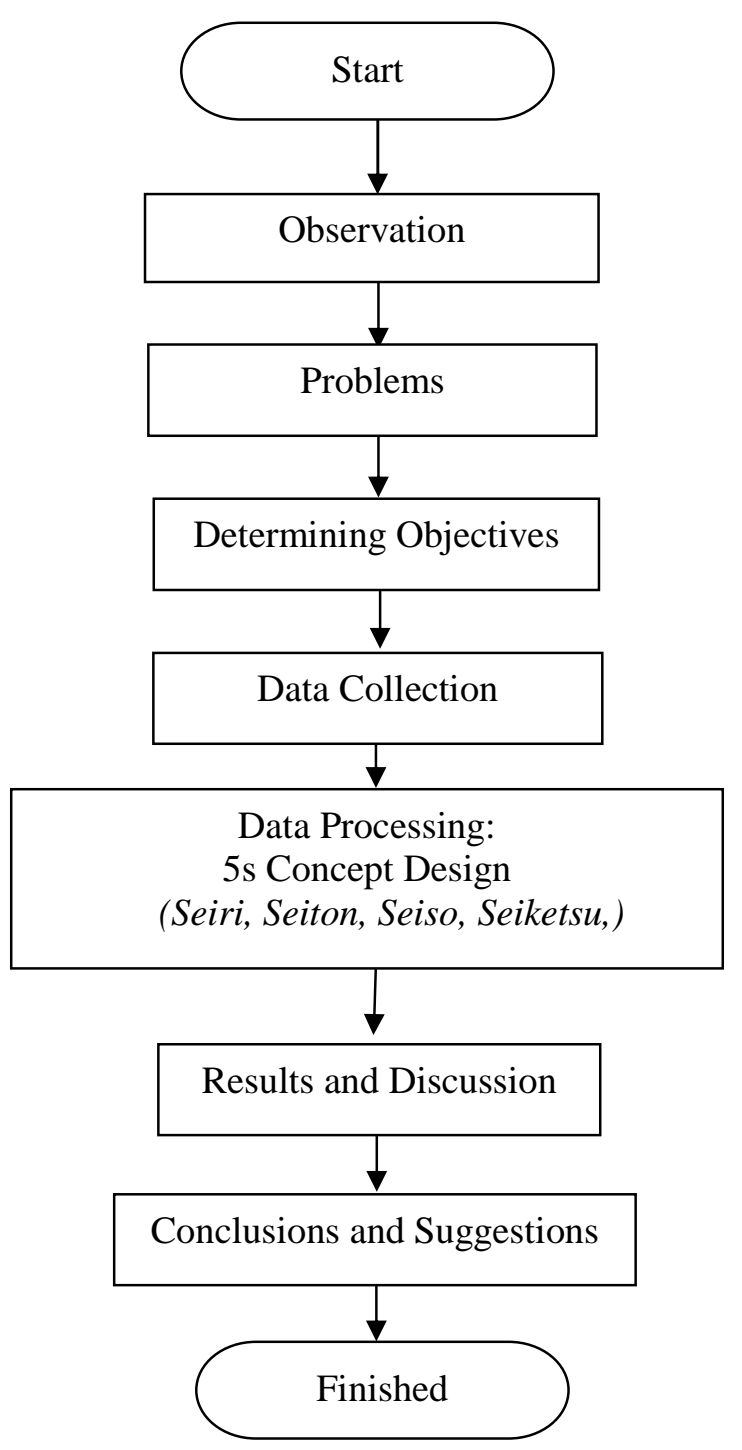

Figure 1. Flowchart Process Flow Research

Preliminary studies are conducted for 2 weeks to find out details of the products found in the warehouse section. The study was conducted with direct observation of the 


\section{TiBuana}

Journal of applied Industrial Engineering-University of PGRI Adi Buana

situation in the company in the warehouse and also analyzed the Level of demand before and after the implementation of Kaizen through $5 \mathrm{~s}$ innovations. At the stage of data collection is the division related to Quality Control division, to perform the cost impact calculation to the company through Kaizen and $5 \mathrm{~S}$.

\section{RESULTS AND DISCUSSION 3.1 Seiri planning (brief)}

The first thing to do is to determine the necessary items and which are not required for now. The purpose of this one-piece design is to remove unnecessary or unneeded items into a temporary storage area. The selection is done with the aim of giving comfort so that the workers can work well and everything looks concise. The following are the steps to be performed in a Seiri implementation in the warehouse area: a.) Determining the criteria of items can be categorized into required items and items that are not required.

b.) Collecting data on goods and tools in the warehouse area.

c.) Determine the action taken for each group of goods.

\subsubsection{Seiton (NEAT) design}

The essence of Seiton's design is that work tools and finished goods or products must have one fixed storage location. The purpose of the design is to facilitate the search of goods, retrieve and restore the necessary tools. This design was done to reduce search time and create a more presentable warehouse layout. Here is a step in designing neatly in the warehouse area:
a.) Make the grouping of finished goods according frequency.
b.) Finished goods placement on the shelf
c.) Designing the warehouse layout of finished goods.

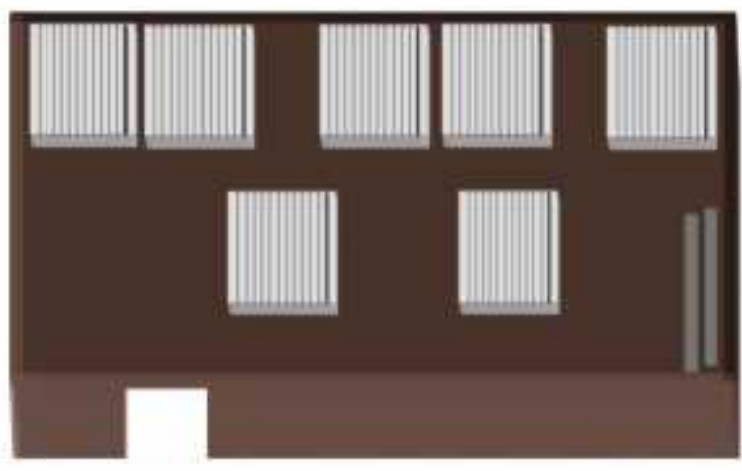

Figure 2. Layout plans before implementation 


\section{TiBuana}

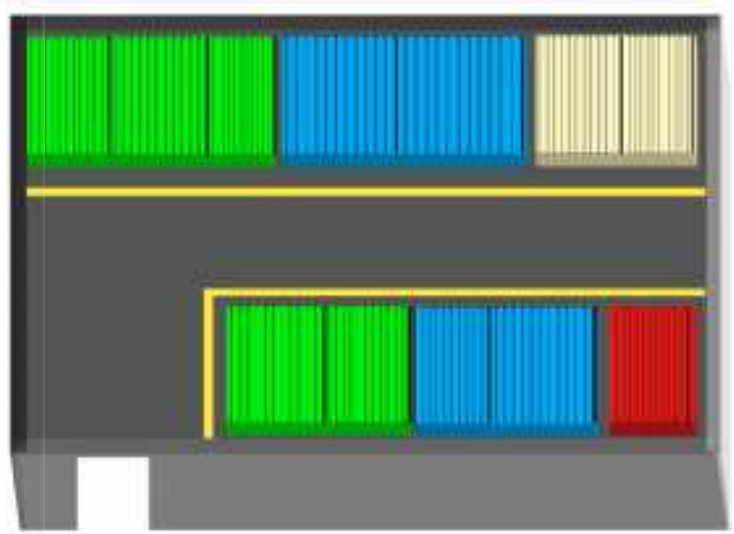

Figure 3. Layout plan after implementation

Description:

Goods with packing green color has a frequency flow of rapid movement of goods.

Goods with blue packing rate frequency flow movement of medium goods.

d.) To provide an item ID

Item ID is done to facilitate the workers in finding goods and avoid the search time and avoid mistakes in the

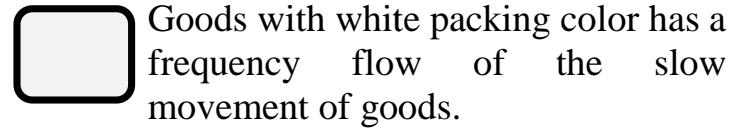

process of preparing a PO (purchase order). The result of the identification of the goods can be seen on the figure 4 below

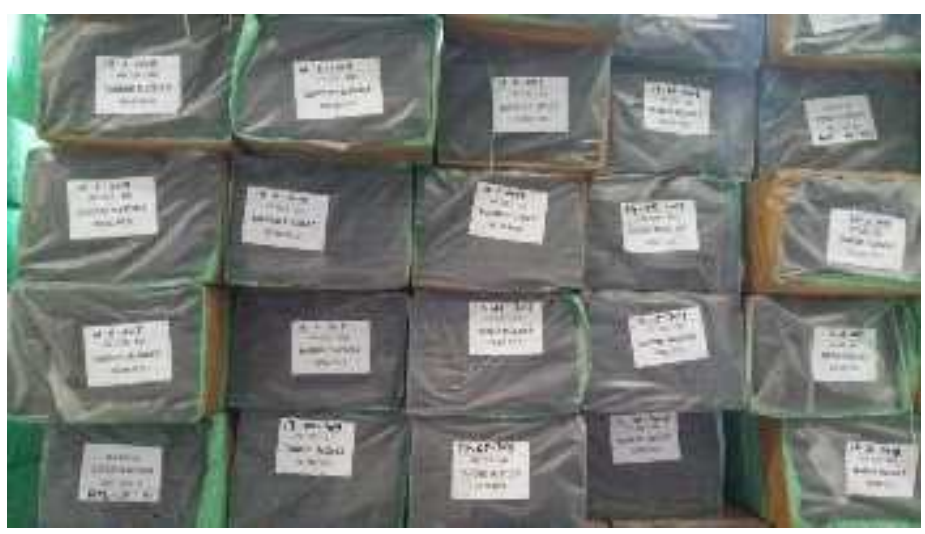

Figure 4. Labelling of the finished product

\subsubsection{Seiso (Resik) planning}

The task and cleanliness is not only carried out the hygiene part of the Narnun become the task and responsibility together in the warehouse area. The purpose of the receipt, making the workplace clean and comfortable for the worker who is checking the task. To run the shine implementation correctly it takes a few steps as follows:

- Record the number of hygiene tools that exist and function. 
Table 1. Hygiene Tools List

\begin{tabular}{clc}
\hline No & \multicolumn{1}{c}{ Tool Name } & Amount \\
\hline 1 & Broom & 2 \\
2 & Dock Sweep & 3 \\
3 & Bellied Warbler & 2 \\
4 & Kemoceng & 2 \\
\hline
\end{tabular}

- Hygiene criteria

Please be aware of what to clean in the warehouse area. At least the workers must know the useless objects in the work area should be removed or moved when the object is still in use. Classified objects must be discarded like, plastic, paper, and other useless objects.

- Responsibilities in each area

After each worker knows what items need to be discarded, it is necessary for the division of work area and responsibility for each worker. The responsibility of hygiene is not only implemented by 1 or 2 workers but all workers will get a turn.

\subsection{4 design of Seiketsu (Rawat)}

The basic core of Seiketsu is how to keep the work area in a neat and clean condition. The implementation of this seiketsu will make the environment always awake continuously. These activities can be done in the following ways:

- Making work area standard is a setting of work area layout, necessary work equipment and areas for hygiene.
1.) The items on the warehouse work desks must be work equipment.

2.) The completed work tools must be returned at the place provided.

3.) The Trash can be placed close to hygiene tools.

4.) Finished goods coming from the production line should be stored in accordance with the name and type of goods.

5.) Finished goods are arranged according to standardization accumulation.

\subsection{5 the design of the}

The main principle of diligent is $5 \mathrm{~S}$ as a culture of work in daily activities. The true $5 \mathrm{~S}$ implementation is the same as changing everyone's habits. The path or not the implementation of $5 \mathrm{~S}$ depends on the willingness of everyone to change the habits they do during this time. Here are practical steps of running diligently:

$\checkmark$ 5S procedure Habituation

$\checkmark$ Carrying out activities "10 minutes 5S" 
Table 2. Data Collection results in setting up a Purchase Order (PO) before and after implementation

Before implementation

\begin{tabular}{|c|c|c|}
\hline Po & Date/month & Time \\
\hline 1 & 27-April & 44.00 \\
\hline 2 & 27-April & 19.00 \\
\hline 3 & 27-April & 40.59 \\
\hline 4 & 27-April & 51.54 \\
\hline 5 & 27-April & 48.29 \\
\hline 6 & 27-April & 54.04 \\
\hline 7 & 27-April & 62.44 \\
\hline 8 & 27-April & 58.11 \\
\hline 9 & 27-April & 31.79 \\
\hline 10 & 27-April & 28.49 \\
\hline 11 & 27-April & 34.56 \\
\hline 12 & 27-April & 39.36 \\
\hline 13 & 27-April & 42.51 \\
\hline 14 & 27-April & 66.96 \\
\hline 15 & 27-April & 24.85 \\
\hline 16 & 27-April & 25.92 \\
\hline 17 & 27-April & 33.39 \\
\hline 18 & 27-April & 30.63 \\
\hline 19 & 27-April & 28.48 \\
\hline 20 & 27-April & 48.23 \\
\hline 21 & 27-April & 49.93 \\
\hline 22 & 27-April & 20.79 \\
\hline 23 & 27-April & 45.72 \\
\hline 24 & 27-April & 42.10 \\
\hline 25 & 27-April & 57.75 \\
\hline 26 & 27-April & 15.95 \\
\hline 27 & 27-April & 48.99 \\
\hline 28 & 27-April & 22.75 \\
\hline 29 & 27-April & 35.62 \\
\hline 30 & 27-April & 27.71 \\
\hline
\end{tabular}

After implementation

\begin{tabular}{|c|c|c|}
\hline Po & Date/month & Time \\
\hline 1 & 27-May & 21.20 \\
\hline 2 & 27-May & 12.45 \\
\hline 3 & 27-May & 23.67 \\
\hline 4 & 27-May & 37.78 \\
\hline 5 & 27-May & 29.92 \\
\hline 6 & 27-May & 36.52 \\
\hline 7 & 27-Мay & 49.12 \\
\hline 8 & 27-May & 32.80 \\
\hline 9 & 27-Мay & 15.10 \\
\hline 10 & 27-May & 11.63 \\
\hline 11 & 27-May & 17.19 \\
\hline 12 & 27-May & 21.77 \\
\hline 13 & 27-May & 19.28 \\
\hline 14 & 27-May & 45.32 \\
\hline 15 & 27-May & 11.54 \\
\hline 16 & 27-May & 15.05 \\
\hline 17 & 27-May & 19.61 \\
\hline 18 & 27-May & 12.88 \\
\hline 19 & 27-May & 12.42 \\
\hline 20 & 27-May & 19.04 \\
\hline 21 & 27-May & 22.76 \\
\hline 22 & 27-May & 7.04 \\
\hline 23 & 27-May & 18.05 \\
\hline 24 & 27-May & 22.73 \\
\hline 25 & 27-May & 44.92 \\
\hline 26 & 27-May & 4.12 \\
\hline 27 & 27-May & 20.34 \\
\hline 28 & 27-May & 14.82 \\
\hline 29 & 27-May & 13.14 \\
\hline 30 & 27-May & 16.20 \\
\hline
\end{tabular}


Table 3. Processingdata Purchase Order (PO) before implementation and after

\begin{tabular}{|c|c|c|c|c|}
\hline No. & Before & After & Different (B) & $B^{2}$ \\
\hline 1 & 44.00 & 21.20 & 22.8 & 519.84 \\
\hline 2 & 19.00 & 12.45 & 6.55 & 49.90 \\
\hline 3 & 40.59 & 23.67 & 16.92 & 286.28 \\
\hline 4 & 51.24 & 37.78 & 13.46 & 181.17 \\
\hline 5 & 48.29 & 29.92 & 18.37 & 337.45 \\
\hline 6 & 54.04 & 36.52 & 17.48 & 305.55 \\
\hline 7 & 62.44 & 49.12 & 13.32 & 177.42 \\
\hline 8 & 58.11 & 32.80 & 25.31 & 640.59 \\
\hline 9 & 31.79 & 15.10 & 16.69 & 278.55 \\
\hline 10 & 28.49 & 11.63 & 16.86 & 284.25 \\
\hline 11 & 34.56 & 17.19 & 17.37 & 301.71 \\
\hline 12 & 39.36 & 21.77 & 17.59 & 309.40 \\
\hline 13 & 42.51 & 19.28 & 23.23 & 539.63 \\
\hline 14 & 66.96 & 45.32 & 21.64 & 468.28 \\
\hline 15 & 24.85 & 11.54 & 13.31 & 177.15 \\
\hline 16 & 25.92 & 15.05 & 10.89 & 118.15 \\
\hline 17 & 33.39 & 19.61 & 13.78 & 189.88 \\
\hline 18 & 30.63 & 12.88 & 17.75 & 315.06 \\
\hline 19 & 28.48 & 12.42 & 16.06 & 257.92 \\
\hline 20 & 48.23 & 19.04 & 29.19 & 852.05 \\
\hline 21 & 49.93 & 22.76 & 27.17 & 738.20 \\
\hline 22 & 20.79 & 07.04 & 13.75 & 189.06 \\
\hline 23 & 45.72 & 18.05 & 27.67 & 765.62 \\
\hline 24 & 42.10 & 22.73 & 19.37 & 375.19 \\
\hline 25 & 57.75 & 44.92 & 12.83 & 164.60 \\
\hline 26 & 15.95 & 04.12 & 11.83 & 139.94 \\
\hline 27 & 48.99 & 20.34 & 28.65 & 820.82 \\
\hline 28 & 22.75 & 14.82 & 17.93 & 321.48 \\
\hline 29 & 35.62 & 13.14 & 22.48 & 505.35 \\
\hline 30 & 27.71 & 16.20 & 11.51 & 132.48 \\
\hline \multicolumn{3}{|c|}{$\sum$} & 539.28 & $10,742.97$ \\
\hline
\end{tabular}

$=$ Average

$\mathrm{B}=\frac{\sum \mathrm{B}}{n}=\frac{5 \quad 2}{3}=17.976$

$\mathrm{SB}===$

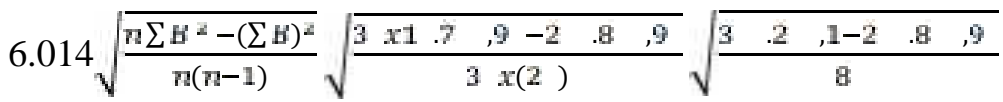

$\mathrm{HO}=$ time in setting up a PO before implementation of $5 \mathrm{~S}=$ time in setting up $\mathrm{PO}$ after implementation.

$\mathrm{H} 1 \mathrm{H} 2 \mu 1=\mu 2 \mu 1 \neq \mu 2$

$\mu 1$; The average time to prepare a $\mathrm{PO}$ prior to an impeleentation of $5 \mathrm{~S}$.

$\mathrm{T}$ count $=\frac{\underline{B}}{S_{\square} / \sqrt{n}}$
$\mathrm{H} 1$ = time in setting up a $\mathrm{PO}$ before implementation of $5 \mathrm{~S} \neq$ time in setting up PO after implementation. $\mu 2$; The average time to set up a PO after an impeleentation of $5 \mathrm{~S}$.

Find T Count: 


$$
\mathrm{T} \text { count }=\frac{\underline{B}}{S_{\mathrm{B}} / \sqrt{n}}
$$

Find T table:

Assumptions using $\alpha 0.05$

$$
\begin{aligned}
& \text { Qt1-1/2 } \alpha(n-1)= \\
& t 1-1 / 2 \alpha(0,005) ;(30-1) \\
& =\mathrm{t}(1-0,025) ;(29) \\
& =\mathrm{t}(0,975 ;(29) \\
& \mathrm{t} \text { table }=2,04 \\
& \text { Ho }=-2.04<16.37>2.04
\end{aligned}
$$

\subsection{DISCUSSION}

The average result of the time to complete the PO after implementation proved faster than before implementation, then Ho rejected. So the implementation of 5S that was done in the Warehouse division of finished goods was declared successful.

\section{THE CONCLUSION}

Based on the results of the design and implementation obtained considerable assessment in the warehouse location. The changes can be proven by the design of layout after implementation :

1. The application of the $5 \mathrm{~S}$

a. The design of the Seiri (succinct), in the Warehouse division of unused goods is

\section{REFERENCES}

1. Mukhtar, M Nushron. "Analysis of the work posture on the operator of the pond machine using Rula method". Scientific articles on research results. University of PGRI Adibuana Surabaya, 2019.

2. Kastoro., Nelfiyanthi "UsulanPenempatanBarang Jadi Di Area Warehouse Produk Jadi DenganKonsep 5sdi PT. NOBI PUTRA ANGKASA" Seminar Nasional Sains Dan Teknologi, Fakultas Teknik Universitas Muhammadiyah Jakarta , November2014

3. Susil,R "Implementasi Kaizen Dan 5S Pada PengeringanProduk Di Proses set aside so that it does not limit the workspace to the warehouse.

b. Designing Seiton (NEAT), finished goods in the warehouse is grouped according to the frequency of movement so that the search time of goods can be reduced and create a more neat warehouse layout.

c. Designing Seiso, the work area on the warehouse looks clean compared to the previous one that still contained waste plastic packing aluminum.

d. The design of Seiketsu (Rawat), each worker can maintain and maintain 3 previous activities namely Seiri, Seiton, and seiso.

e. The design of the...-The worker can maintain personal discipline For all the $5 \mathrm{~s}$ activities that have been applied.

2. The results of other proof can be seen in the results of photographs, statistical test results with an average comparison that shows the average time before implementation is 16.37 and the result after implementation is 2.04 and this proved that after implementation is experienced a significant decline so in service purchase order (PO) faster, $5 \mathrm{~s}$ implementation done in the Warehouse division of finished successful.

Plating "Jurnal Teknik Industri, Vol. 18, No.02, Agustus 2017, pp. 121-126 ISSN 1978-1431 print / ISSN 2527-4112 online https://doi.org/10.22219/JTIUMM.Vol18. No2.121-126

4. Khan, "KAIZEN: the Japanese strategy for continuous improvement," VSRD International Journal of Business \& Management Research, vol. 1, pp. 177184, 2011.

5. H. Chi, "1 5S implementation in Wan Cheng Industry Manufacturing Factory in Taiwan," 2011. T. Ohno, Toyota production system: beyond large-scale production: crc Press, 1988. 